\title{
PPP Approach in Development Aid
}

\author{
조 광 걸 $\mathrm{KOICA} O \mathrm{OAA}$ 교육원 팀장
}

\section{목 차}

1. Introduction

2. Overview of current practices and DAC's position

3. Contribution

4. Conclusion

\section{Introduction}

Rational: Discussions on aid effectiveness have recently gained popularity and become more heated. One side points out that aid not only provokes corruption and, erodes social capital, but also chokes off export-growth due to the Dutch disease, just like the oil curse does. Aid is also claimed not to contribute to poverty reduction or economic growth in developing countries, and it is even claimed that current aid practice should be stopped (Moyo, 2009). The other side opposes this assertion, and maintains that aid has worked; the volume of aid should be increased to bridge the wide gap between the necessary investment and current level (Sachs 2005).

The private financial flows have rapidly increased as shown in figure ${ }^{1)}$. Foreign Direct Investment (FDI) as of 2010 was reported at HLF-4 in Busan that it has increased up to $\$ 600$ billion, approximately 6 times of $\$ 128$ billion worth of ODA; and in 2010 remittance flows into developing countries amounted to $\$ 325$ billion, which accounts for nearly three

1) 'The Index of Global Philanthropy and Remittances 2010', Hudson Institute, recited 'Policy and Issues on Development Cooperation', KOICA (2011.6). Similar graph was introduced in Journal of International Development Cooperation, KOICA, No.3, 2009, author based on DAC data. 
times ODA volume. Remittance flows to developing countries have proven to be resilient during the global financial crisis, with 2010 figures shows $6 \%$ increase from the 2009 level2). Meanwhile the proportion of NGO's contribution within development has also sharply increased from $10 \%$ in the latter 1990s up to $19 \%$ in 2008. Furthermore some foundations e.g. Bill \& Melinda Gates foundation3) provided some $\$ 3$ billion worth of aid in 2009, which is bigger than Korea's ODA volume of 2009.

Contrary to the private sector's active engagement, voices demanding an increase in ODA volume have been weakened by fiscal constraints and the global financial crisis. Making ODA more efficient through facilitating private participation is one of the options that government can take, in addition to consideration of ODA scale-up and its effectiveness. With the influence of neoliberal ideologies on public policy including development policy, public-private sector partnerships have been promoted. The 'Busan Declaration' in particular marks an epoch in making a turning point of aid's role; "Aid is only part of the solution to development... aid catalyses development." $\left.{ }^{\prime}\right)$

Figure 1. DAC member countries resource flows to developing countries

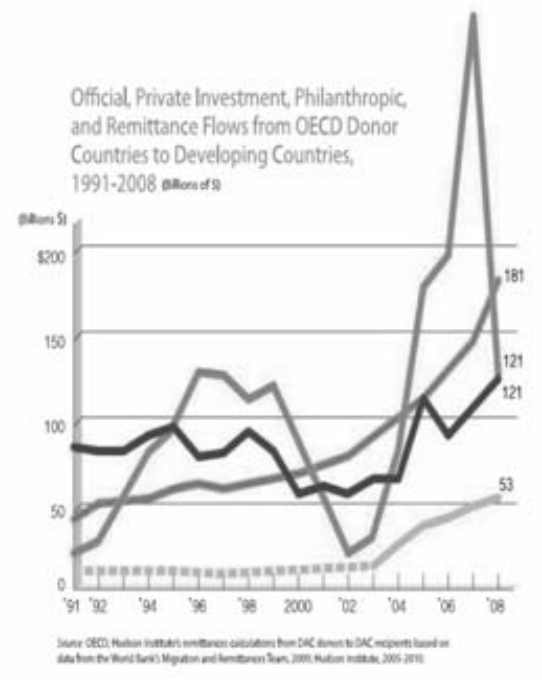

Rodrik (1994) revealed that Korean government in 1960-70s used a combination of public and private intervention, "thereby raising the private returns to capital $\cdots$ to the level of the social return" (p.30). Broadening new market opportunities and sharing risk of projects can maximize the social return of the investment: the raison d'etre of PPP. Hubbard and Duggan (2009) claimed that 95\% of total aid is executed by the government and NGOs, while $5 \%$ of the aid is in charge of local business. Hubbard also asserted that "the percentage should be 50-50" based on the findings that local government continues to

2) Retrieved from http://data.worldbank.org/data-catalog/migration-and-remittances, 2011.Aug.12.

3) http://www.gatesfoundation.org/annualreport/2009/Pages/grants-paid-summary.aspx

4) 'BUSAN PARTNERSHIP FOR EFFECTIVE DEVELOPMENT COOPERATION', retrieved from http://www.aideffectiveness.org/busanhlf4 (2011.12.5) 
suppress the local business sector through utilizing the 95\% "non-business aid". 5)

Concept: According to Kirkemann \& Applelquist (2008), PPP terminology was first introduced as a concept of its efforts to make the public sector more effective in the United Kingdom by the Conservative government in 1992. A PPP approach can address pressing demand on public services without increasing the indebtedness of public entities by drawing on private sector capacities; innovative management and financial mobilization. These schemes constitute a creative method for procuring public services and infrastructure with an emphasis on value for money and delivery of quality in public services.

A number of development agencies6) also adopted the PPP during the 1990s. The common characteristic of the definitions adopted by many donors is that PPP is regarded as a contractually established entity (Kirkemann \& Applelquist, 2008).

$\mathrm{ADB}$ refers key characteristics of PPP as 'sensible risk-sharing among the public and the private sector partners', and 'financial rewards to the private party commensurate with the achievement of pre-specified outputs' (ADB, p11). In order to get a whole and clear picture of PPP, it may be helpful to make difference between other approaches such as privatization, joint venture and concession, etc. Meanwhile the pattern of PPP can be classified on basis of risk sharing degree such as Operation-Management, BOT (Build-Operation-Transfer), BOO (Build-Orn-Operate).

Figure 2. Various Approaches of PPP

Motive: Private sector can have new opportunities to enter into public sector with benefits of sharing the risks of investment; to internalize the operational and maintenance costs of the investment during the construction phase. PPP can apply to not only infrastructure, but also other sector such as health, telecommunication, etc.

Generally speaking, governments can be motivated to enter into a PPP approach due to

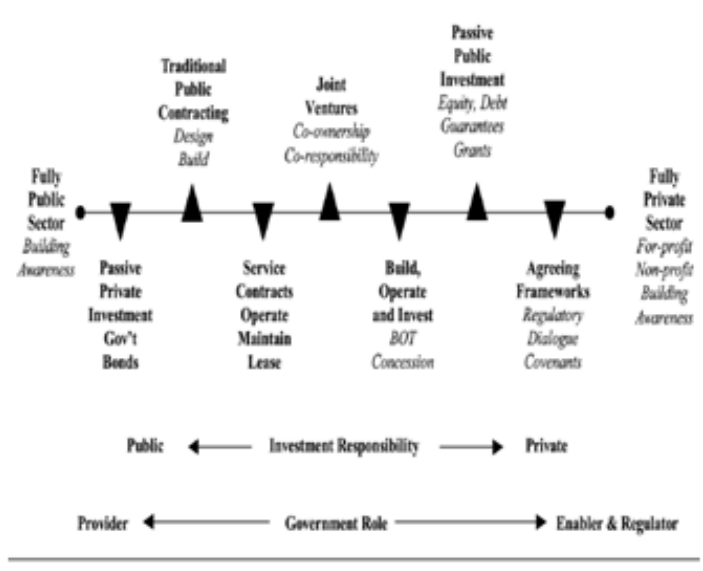

Source: Gidman et al. (1995)

5) http://cup.columbia.edu/static/hubbard-interview-aid-trap

6) Relevant donor agencies' definition of PPP is presented in Annex 1. 
the following aspects (ADB, p11);

(1) to attract private capital investment (often to either supplement public resources or release them for other public needs);

(2) to increase efficiency and use available resources more effectively; and

(3) to reform sectors through a reallocation of roles, incentives, and accountability.

PPP has been usually executed within one country, sometimes carried out across border lines. The global version of PPP has been projected between donor(s) and recipient(s). The PPP which is applied to the international aid or development can be referred as 'PPP in Development', comparing domestic PPP in developed or developing countries. Stakeholders of PPP in Development i.e. donors, recipients and corporation may hold different positions. Donors can tap more resources for international development, and bring private sector efficiency into public sector bureaucracy. PPP may not only promote the development awareness and bolster influence within recipient countries, but also it can improve business enabling environment for national companies. Recipients are appreciative of additional resources and advanced Operation \& Management (O\&M) skill for selected projects while critics show concerns on corruption, leakage or diverting domestic resources from national priorities. Corporations can gain access to policy-makers, increase their influence not only at the national level but also in global trade. In addition, PPP can provide corporations with direct financial benefits or tax break. Corporate brand and image could be promoted through PPP activities; Public Relations events which include a gala function at UN, and a major feature in the mass media. PPP can present 'Triple-Win' solution for donor, recipient, and corporation.

\section{Overview of current practices and DAC's position}

\subsection{Major donors' current practices}

The majority of donor agencies have now adopted the PPP methodology into their aid programs even though various version of PPP has been made depending on agencies' different context. Several donors' PPP practices can show their estimate of what kinds of the PPP programs is operated as one of their aid programs. 
First, U.S.A. operates an American version of PPP called the Global Development Alliance (GDA), which it uses as its business model to combine the assets and energy of corporations, foundations, nonprofit organizations with those of donor agencies in order to expand development assistance to the world's poorest countries. The GDA transforms and redefines the way USAID does business, shifting away from the traditional client-vendor relationship to welcoming the private sector as full and equal partners on development projects. As a result, USAID has cultivated more than 600 public-private alliances with over 1,700 unique partner $\mathrm{s}^{7)}$, and leveraged $\$ 5.8$ billion in resources from partners with $\$ 2.1$ billion in public investment (Clapp-WincekCynthia 2004). Dr. Shah, Administrator of USAID, introduced Development Credit Authority (DCA) program at HLF-4 in Busan, which aims to stimulate lending through partial credit guarantees to SMEs in particular which cannot access banking credit in developing countries. This credit has incredible leverage effect; reportedly 2.3 billion US\$ was additionally invested from the local finance with 82 million US\$ from USAID. ${ }^{8)}$

Second, the Canadian version of PPP, called CIDA-INC, was established in 1978 with dual purpose: reinforcing the image of the Agency in the business sector and fostering new ventures in the developing countries. Its goal is to encourage the Canadian Private Sector to establish long-term business relations with developing countries in order to promote and support socio-economic development and poverty reduction according to the internal evaluation report (CIDA, 2007). From its inception in 1978 until 2005, numbers of 8,138 proposals had been approved, 972 projects were subsequently implemented. Statistically, however, only $8.8 \%$ of total budget spent by CIDA-INC during 1995 to 2005 was disbursed in the 9 partner countries which are poorer and have more difficult business environment.

Third, Japan launched the PPP in 2008 to accelerate economic growth for poverty reduction and has particularly engaged in the infrastructure sector. Japanese PPP is expected to play a role in enhancing the enabling environment for private sector development and play a leveraging role of, e.g. providing various forms of guarantees for project risk. Japanese PPP expects collaboration with the private sector to implement Corporate Social Responsibility (CSR) or Bottom of the Pyramid (BOP) business models to scale up

7) It has been increased to about 3,000 partners, according to Dr. Shah's announcement at Busan Forum.

8) Retrieved from http://www.usaid.gov/our_work/economic_growth_and_trade/development_credit/ (2011.12.7) 
development outcomes (DAC, 2010,p7).

Fourth, Netherlands has been progressive in the private sector's role for aid effectiveness. Netherlands Ministry of Foreign Affairs has an Ambassador for MDGs and PPPs, and is currently involved in 75 PPP projects which invest a total of $€ 750$ million between 2003 and 2012, while the business community and other partners are contributing a total of $€ 1.48$ billion (DAC, 2010, p5).

\subsection{DAC's review}

As a major contributor to growth, the private sector in developing countries should be centrality of donors' efforts to reduce poverty in a substantial and sustainable way. According to the DAC's study (DCD, 2008) regarding the role of ODA to promote private investment for development, the focus of the previous practices has often been on firms in donor countries, rather than market outcomes. The DAC (2006, p7 8) made a review on the past practices which were executed by development agencies;

1) Donors are supporting a vast range of activities - at the macro-economic, enabling environment and enterprise levels - that affect investment. They spend around $20 \%$ of their aid on these. But little evaluative material on the impact of interventions on promoting investment is available.

2) Insufficient attention has been given to enterprise and supply-side capacity development, and to promoting the institutional and policy reforms that lie at the heart of efforts to promote private sector development.

3) Donors have focused too much on assisting specific types of firms (e.g. certain sizes, activities or sectors). Experience has shown this can lead to market distortions and poor sustainability.

Keeping the above review in mind, the DAC (2006) established guidelines which promote private investment for development, mainly recommending not only facilitating additional investment, and promoting business-friendly environment, but also creating jobs, supporting institutional reforms in developing countries ${ }^{9}$. The DAC (2006, p21) maintain in its paper which also provides a comprehensive and insightful guidepost for PPP; PPP should help promote private investment.

9) For detail, refer to Annex 2. 


\subsection{Pro-poor PPP cases}

$\mathrm{ADB}$ among multi-development banks has a new strategy for mainstreaming PPPs for 2011-2020 and upcoming operational plans for first quarter of 2011. This includes the development of new financial and risk-sharing tools to support PPP and infrastructure projects (DAC, 2010, p10). The pro-poor PPP that is proposed by the ADB can be a prospective alternative in order for PPP to contribute to relieve poverty in developing countries. For a case, as an incentive for private telecommunications operators to expand service to rural areas of the country, Peruvian government structured Public-Private Partnership (PPP) arrangements that award a subsidy for pay phones installed in target areas. Payment of the subsidies is linked to performance; first payment upon award of the contract, second part once the pay phone has been installed, and the remainder in semiannual installments over the life of the contract. These payments were tied to the operator's achievement of key performance indicators. This structure does not only provide incentives to operators to extend service to low-income areas, but also set equal priority on the maintenance of infrastructure and provide the quality of service to low-income customers (ADB, 2006, p83).

Meanwhile, Danida's PPP program can be one of the representative global PPP programs in DAC member countries. Martinussen \& Pedersen (2003, p91) explain that the Private Sector Program supports establishment of commercially promising and sustainable cooperation between Danish corporate and corporate in developing countries. It extends counseling and grants for various activities: identifying partners, mutual visits, preparatory studies, and training, dispatching experts, export promotion, environmentally sound production.

For an instance of this type PPP, the project titled "Implementation of CSR in the Cocoa Bean Production in Ghana" was implemented with Danida's 60\% contribution ${ }^{10)}$ from 2007-10. Starting this project was initiated with harsh criticism in the media on the use of child labor in the production of cocoa in West Africa. Danish cocoa importing company, Toms, decided to get involved in trying to improve the working condition e.g. changing farming methods rather than stopping import of cocoa. Its overall objective is that the Ghanaian education sector and civil society ensure children enjoy their right to achieve basic quality education. Within this context, the project has two long-term objectives, which leads

10) Its total budget scale amounts DKK $7,973,198$ with Danida's contribution of $60 \%$ up to DKK 4,750,000. 
to poverty alleviation; to increase the incomes and improve working conditions of Ghanaian cocoa farmers through changing production process; to improve access to quality education, governance, accountability and advocacy.

Kirkemann \& Applelquist (2008) evaluated this PPP from various aspects such as Danida's guideline consisting of six development impact criteria11), DAC evaluation criteria ${ }^{12}$, Global Compact principles ${ }^{13)}$, and the PPP intervention objectives as well. To sum up, the ownership and sustainability was secured by the inclusion of private and public sectors as well as by broadly institutionalizing new practices and procedures. The efforts which were made to partner with institutions ${ }^{14)}$ of private and public provide the basis for sustainability (Kirkemann \& Applelquist, 2008, p21-22 of Annex4). As pointed out by Martinussen \& Pedersen (2003), "[T]he intention [of Danida's PPP] is not to maintain partnerships but to function as a catalyst for establishing and then phasing out public support” (p91). In fact, the local partners are not subsidiaries of Danish company, Toms.

\subsection{Infrastructure PPP case}

In 1996 both governments of post-civil war-stricken Mozambique and post-apartheid South Africa developed the concept of the Maputo Development Corridor (MDC) to foster transport

11) 1. Promotion of human and workers' rights

2. Protection and improvement of the environment

3. Promotion of sound business practices

4. Promotion of gender equality and empowerment of women

5. Combating HIV/AIDS, malaria and other diseases

6. Promotion of innovative partnerships for investments and competitiveness

12) Relevance, Efficiency, Effectiveness, Impact, Sustainability

13) (Human Rights)

Principle 1: Businesses should support and respect the protection of internationally proclaimed human rights; and Principle 2: make sure that they are not complicit in human rights abuses. (Labor)

Principle 3: Businesses should uphold the freedom of association and the effective recognition of the right to collective bargaining;

Principle 4: the elimination of all forms of forced and compulsory labor;

Principle 5: the effective abolition of child labor; and

Principle 6: the elimination of discrimination in respect of employment and occupation. (Environment)

Principle 7: Businesses should support a precautionary approach to environmental challenges;

Principle 8: undertake initiatives to promote greater environmental responsibility; and

Principle 9: encourage the development and diffusion of environmentally friendly technologies.(Anti-Corruption) Principle 10: Businesses should work against corruption in all its forms, including extortion and bribery.

14) For example, educational authorities and "cocoa board" were included. 
and trade between the two countries. The N4 toll road which linked from Witbank of South Africa to Maputo of Mozambique was one of the MDC's projects which include facilitating the rehabilitation of Maputo Port and the revival of the Garcia railway. Mozambique, however, did not have the money for financing the project and the South African government also faced an accrued debt for road infrastructure. Both governments faced major hurdles in attempting to maintain an efficient and well-operated road system. Thus the PPP approach was an appealing way of securing private financing and innovative management.

The Trans African Concessions (TRAC) planned to build and operate the N4 toll road as a private consortium. After the 30-year period, control and management of the road reverts to the governments. The governments of South Africa and Mozambique jointly and severally guarantee the debt of TRAC which was worth R3 billion (at 1996 estimates) and, guarantee the equity as well under certain conditions (FarlamPeter, 2005, p10).

This international PPP has facilitated the growth of tourism in the region as well as other sector investments in Mozambique such as the aluminum smelter and the natural gas plants. Some valuable suggestion and lessons from the above PPP case are as follows;

- The commercial risk was shared between a range of partners: The N4 was financed from $20 \%$ equity and $80 \%$ debt by the construction companies, Pension Fund, regional banks, various private sectors and regional development banks, etc.

- Cross-subsidization (from the more affluent South African users) and substantial discounts for regular Mozambican users helped to reduce the user payment risk; there was considerable user payment risk in Mozambique as the poor communities were unable to pay high toll fees. The two governments have wide gap in per capita GNI between $\$ 188$ and 3,918 in 1998 (Human Development Report, 2000).

- The road facilitated further private sector investment in Mozambique, which in turn raised traffic volumes

According to the guiding principles ${ }^{15)}$ offered by InfraPoor of DAC, the N4 toll project is quite a success; neighboring poor people could have more income and wider job opportunities

15) i) Use partner country-led framework as the basis for coordinated donor support

ii) Enhance infrastructure's impact on poor people

iii) Improve management of infrastructure investment, to achieve sustainable outcomes

iv) Increase infrastructure financing and use all financial resources efficiently 
with road infrastructure project. All possible financing resources efficiently utilized with harmonized collaboration of stakeholders. It could be a representative case of South-South cooperation in the field of PPP as well as international PPP case.

\subsection{Korean PPP cases}

\subsubsection{Domestic Korean PPP}

The Korean government has tried to make the best use of PPP projects domestically, and could be one of the best practicing PPP countries in the world. Domestic PPP has been well developed and institutionalized since it may deal with considerable scale of money and directly utilize taxpayer's money. Korea first introduced domestic PPP projects in 1995, which amounted 400 million $\mathrm{W}$ mostly as type of build-transfer-operate (BTO). Up to late 1980 since its inception, however, 3.7 trillion was invested in PPP, taking up about 18.4\% of total SOC investment. Main motives to promote PPP in Korea are to mobilize private resources, and to take advantage of creativity and efficiency of the private sector. Korean government promoted PPP projects instead of cutting down national investment considering the effects of investment in social infrastructure on the national economy. Korean PPP is based on a special Act that precedes other Acts, and has hierarchal legal framework. Candidate projects should be scrutinized by the Value for Money (VFM) test, which is designed into three phases: first 'Decision to Invest' stage to confirm whether or not a project is worth the social benefit; second 'Decision to Implement by PPP' stage to determine whether a project is suitable to be implemented by Private Finance Initiative (PFI) after comparing with the Public Sector Comparator (PSC); third 'alternative PPP implementation'.

As of 2009, a total of 242 BTL projects were completing, with a budget of some 12.2 trilliW, which included projects involving 136 primary and middle schools, 56 environmental sewage facilities, 10 military residential facilities and 18 cultural facilities. Unsolicited projects, which private companies can initiate rather than central or local governments do, have been executed at more than double the rate of solicited ones: 266 vs. 103. In short, facilitating private participation has been successful. PPP approach help increasing Korean GDP growth as KDI macroeconomic model shows; the impact of PPP on GDP growth estimates 0.198\% in 2008. (Jay-Hyung Kim et all, 2011) 


\subsubsection{Korean PPP in Development}

In line with promoting awareness of CSR and Global Compact (GC), Korean business sectors show deep interest in alleviating poverty in developing countries and development arena including ODA. The PPP in Development, which PPP is applied to development aid program, is recognized fairly recently as a new type of aid activities. With CSR being recognized and discussed, the KOICA introduced a PPP program with amount of $\$ 1$ million in 2010, and doubled its PPP budget in the following year. A priority is set to Least Developed Countries (LDCs) and Africa, and to create jobs in developing countries, while it is prohibited from contributing to the specific corporate profit.

Five projects in developing countries were initiated in 2010 with total budget support of $\$ 1$ million ${ }^{16)}$; one program which is executed in five Africa countries ${ }^{17)}$, called 'Community-Driven Development 'BRIDGE' Program', aims to foster a community leading group and to set up community schools for further community development. Its type is a tripartite joint program among Samsung Electronics, the Korea Commission for UNESCO which leads the Education for All (EFA)18) for Africa, and KOICA with integrating respective stakeholders' comparative strength i.e. funding, official system, access to public networks, expertise, and locality. For 2011, KOICA selects ten PPP programs which intend for relieving poverty and improving social services. These includes; a project to set up solar streetlights within the Angkor Wat in Cambodia, which is co-financed with Asiana Airline Inc.; a village project for poverty reduction in Mozambique, which is co-worked by POSCO and Korea international NGO, KFHI (Korea Food for the Hungry International).

KOICA's PPP is projected on a matching grant basis, which is 50:50. In other words, any private company which is willing to join the KOICA's PPP has to finance at least 50\% of total project cost. This means that KOICA can leverage its grant aid to increase the pro-poor programs in developing countries by at least $100 \%$ from the start of each project. This policy is in line with DAC's position which PPP should contribute to attract additional investment from the private sectors. It also turns out to have similar leverage effect of GDA which is

16) PPP program for 2010 retrieved from KOICA homepage, 2011.Aug.12.

17) Rwanda, Malawi, Lesotho, Zimbabwe, Rep. of South Africa

18) The Education for All (EFA) movement is a global commitment to provide quality basic education for all children, youth and adults. The movement was launched at the World Conference on Education for All in 1990 by UNESCO, UNDP, UNFPA, UNICEF and the World Bank. 
American version of PPP, and Danida's PPP program.

Current PPP interventions of KOICA could be classified as a pro-poor PPP by the criteria of $\mathrm{ADB}$ since they focus on improving social services for the poor rather than investing infrastructure. If Korean PPP intends to assist economic growth of recipient countries, loan program which is comparative much larger one could fit better the grand infrastructure for developing countries. Korean EXIM bank which is in charge of concessional loan tries to contain the PPP approach. To develop efficient and innovative financing methods at design stage as well as to organize the Special Purpose Company (SPC) during process period will play a pivotal role in making PPP a success.

\section{Contribution}

Typology of PPP: DAC emphasizes the impact of infrastructure on reducing poverty as well as economic growth ${ }^{19)}$. And yet the ADB (2006) classified the PPP which applied to development program into two types; Infrastructure PPP and Pro-poor PPP. This is understood as a consideration of argument on whether infrastructure makes positive impact on poverty reduction, or as a reflection on which is the main objective of a relevant project. Either understanding is acceptable in that the ADB classification presents a clear guidepost: economic development or social development - despite accepting DAC's integrated stance.

However, ADB classification does not present management concepts in dealing with PPP. The private returns to capital could be raised to the level of the social return with a management tool. Under this notion, PPP can be classified into three categories: first, the market-initiated or government-initiated PPP according to which partner has more initiative; secondly infrastructure PPP or pro-poor PPP depending upon PPP's initial and direct objective; thirdly domestic or global PPP upon who is the main stakeholder, local government or multi/bi-lateral donors. The market-oriented PPP, in which a corporation has initiative, may utilize more technical assistance or grant type of ODA rather than loan

19) In 2003, DAC chose infrastructure as a major area of analysis for its Network on Poverty Reduction (POVNET), and The Task Team on Infrastructure for Poverty Reduction (InfraPoor) was created to guide efforts of DAC members. 
programs. In case of loan, delicate mixed financing is required to plan especially for infrastructure projects. The Global Compact which can guide the private sector not to be indulged into business profits may be a better rationale for market-oriented PPP. On the other hand, government-initiated PPP should consider comparative scale of social benefit, economic feasibility through Value for Money test in order to avoid over-supply.

The pro-growth PPP which mainly deals with infrastructure sectors is financed often by loan rather than grant, while technical assistance can play a part in drawing up a Feasibility Study or Master plan. Loan programs may require state-of-art financial engineering to minimize project risk as well as to mobilize necessary money. With multiple stakeholders involved, the Special Purpose Company (SPC) may play a pivotal role in making PPP project a success, and anti-corruption method should be taken into account. Additionality, which means inducing additional investment from the private sector, should make a key centrality of this PPP. Specific project arrangements which lead the objective and process of the PPP should reflect the guidelines of DAC and Global Compact. The pro-poor PPP may attract technical assistance or grant rather than loan programs. This approach,

Figure3. Typology of PPP

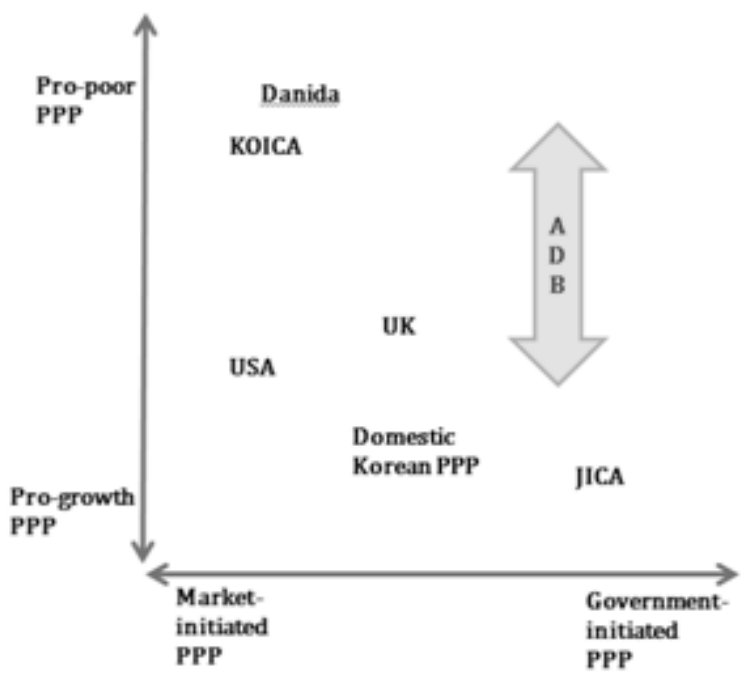
however, may probably have drawbacks in additionality. Meanwhile the solicited approach through which private sectors can join with public ready-made plans for feasible projects can provide a stronger foundation for additionality.

In the case that concessional loan program involves a pro-poor PPP, the PPP needs more attention on the poor people and financial conditions i.e. longer grace period, lower interest rate, etc. In case of pro-poor PPP with low additionality, the PPP need to develop innovative approaches e.g. solicited selection method. Activating the pro-poor PPP recommends a risk-loving approach rather than being risk-averse20). The PPP is still an evolving aid development tool, which has various conceptual ambiguities surrounding the terminology: its 
definition, scope of target, various actors, and modality to promote effectiveness. Classification hitherto provides comparative borderlines for management rather than clear-cut guidelines.

Recommendation: It deserves high opinion for KOICA to adopt matching grant method, which results in amplifying its leverage effect, namely additionality;21) and to take pro-poor approaches in selecting PPP projects; and to prohibit private partners from pursuit of profits only. Considering PPP's endogenous strength, KOICA's PPP in Development is expected to help the poor people escape from poverty trap, and contribute to achieving socio-economic development and ultimately "attainment of MDGs impossible without PPPs" (UNDP, recited by Kirkemann).

Nevertheless, there is a need to develop effective models aligning global guidelines as well as to set right regulations and an appropriate strategy under the conceptual ambiguity of PPP. The present selection criteria of KOICA PPP in Development partly aligns with DAC evaluation guidelines; relevance, efficiency, and effectiveness, and yet the criteria should develop clearer linkages with Global Compact 10 principles if CSR insists to be at the head of its PPP selection criteria. CSR is still recognized partly as one option for a business strategy, or one of pure Public Relations. ${ }^{22)}$

Concerning relationship between CSR and PPP, we need to be deliberate. The two has different philosophical and methodological background, and international organizations have not yet a shared view on the relationship. First, CSR begins from the corporate point of view and recognizes social relationship; contributing social value, or the idea of 'doing no harm'. With globalization debates on CSR go well beyond the borders of corporations. That is why ISO26000 covers not only corporate but other form of organization e.g. labor union, so understandably it is recognized as Social Responsibility (SR) instead of Corporate Social Responsibility (CSR). On the contrary, PPP is devised from the perspective of government which provides public goods and services as public servants. Private sectors in PPP in Development should and de facto include non-profit organizations as well as pro-profit companies. Second, Global Compact understands that PPPs are means towards reaching the

20) Busan declaration refers to 'innovative' as well as 'risk managing' approach in the clauses of the private sector and result-based development approach (clause 18, 32 in the Statement)

21) DAC (2006) emphasizes additionality in PPP, which means attracting additional investment from the private sectors.

22) For the former, D. Vogel, "The market for virtue", for the latter, Milton Friedman 
ends defined by CSR - CSR is the goal or the ideal, but ADB defines that "Public private partnership (PPP) has been recognized in sustainable development as a leading success factor towards sustainability and efficiency." (KirkemannApplelquist 2008, refers to Annex1). If it is inevitable, then it seems more appropriate to adopt SR or ISO26000 approach rather than CSR.

Concerning the operational point of view, the current "unsolicited" approach of selecting private partners may accelerate private participation in PPP at initial stage. It also helps to relieve pains in finding appropriate PPP candidate projects. With the accumulation of relevant experiences regarding PPP, however, KOICA may invite private partners to join with KOICA's specific projects. This solicited approach can strengthen synergy effects of PPP on KOICA's development program since private sectors can join KOICA specific projects which are well organized, aligned with local government policies. This approach may not only need an effective framework for relevant projects, but also active involvement of private entities. Solicited approaches can also provide more appropriate foundation for additionality since private additional fund is induced into ready-made plans for public projects. As a start-up, After-Service (A/S) PPP could be one option, which invites private sectors to the terminated projects e.g. hospital projects. ${ }^{23)}$

Either solicited or unsolicited PPP approaches will provide chances for private sector to join in ODA activities. Close coordination and cooperation between public and private sectors can improve absorptive capacities in poor countries and remove bottlenecks to aid effectiveness (Addison T. \& Mavrotas G., 2005). For example, Korea stands as "a leading example" of how well government can promote an extensive school-based Vocational Education and Training (VET) (ADB, 1991, p53-55, recited in Tilak, 2003). VET has more advantages than general education in making more income and narrowing gender earning differentials according to a statisitcal analysis on Singaporian case(Sakellarious, 2006). When a company intends to invest in manufacturing facilities in poor countries, the VET center can be established through PPP to bring up skillful workers and to link with job opportunity for e.g. small and medium enterprises (SMEs). While South Korean textile manufacturer Sae-A's investment was introduced at HLF-4 in Busan by Secretary of State, Hillary R. Clinton as a showcase of private sector's role in job creation ${ }^{24)}$, KOICA can extend

23) This proposal which was made by author in Journal of International Development Cooperation, KOICA, No.3, 2009, is supposed to launch from 2012. 
VET program in Northern Industrial Park of Haiti rather than primary education which has been emulatively supported by other donors. This aligns with UNIDO's position, saying "Partners can be an effective industrial development tool ‥ for SME development." The European Fund of Southeast Europe (EFSE), which was selected as one of the 14 world best Public-Private Partnership (PPP) models at the G20 Summit in Seoul for the innovative financing of SMEs, has created some 215,000 new jobs since the fund's inception in 2005. ${ }^{25)}$

Besides, sustainability and scalability of PPP are crucial factors for successful development. Budget scale for PPP is recommended to be increased in; both the whole PPP budget and unit allocation. Multi-year support based on performance is necessary to secure both sustainability and impact of the PPP project. Activities on monitoring and evaluation (M\&E) should be promoted, and regulations must be strengthened to align with DAC guidelines, CSR and GC principles. Monitoring and Evaluation (M\&E) will prevent corruptions and guarantee the PPP'S quality as pointed out by CIDA (CIDA, 2007). And it also requires branding26) when other donors' precedents are kept in mind, rather than putting CSR at the front of KOICA PPP.

\section{Conclusion}

Private financial flows can encourage economic growth and relieve poverty because they create excellent incentives for transferring know-how, and are subject to a stern market test that ensures money flow's allocation and monitoring, while aid flows are not automatically subject to these disciplines (Klein \& Harford, 2005, p71). Furthermore, ODA's impact on economic growth per se is still under debate, with some arguing that even infrastructure assistance is vulnerable to fungibility of up to $90 \%$ (Chatterge et all, 2007, p13), that technical assistance mostly goes for donor's experts not for recipients, and that food aid should be halted. ${ }^{27)}$

24) In her official speech at ministerial sessions on 30 Nov, 20,000 jobs will be created with 70 mill US\$ that is invested by a private company, Sea-a. It is a co-invested project with other development bank e.g. IDB.

25) It facilitated over 247,000 loans, totaling just under EUR 1.3 billion. FRANKFURT, Nov. 2 AsiaNet41993.

26) For example, "Change-Maker Korea", "Social Entrepreneurs Korea" for KOICA PPP; GDA (Global Development Alliance) for USA, IPD (Innovative Partnerships for Development) for Denmark, B4D (Business for Development) for Sweden, etc.

27) Alex de Waal, 'Famine crimes : politics \& the disaster relief industry in Africa', (1997) 
The double gap, however, of domestic savings and foreign exchange stock for development is endemic in poor countries. As recognized in the Busan Declaration, aid can play a role of catalyzing private sectors' additional investment. And the statement emphasizes that the private sector has a "central role in advancing innovation, creating wealth, income and jobs, mobilizing domestic resources and in turn contributing to poverty reduction”. ${ }^{28)}$ Thus a PPP, which can refer to a hybrid technology between public and private sectors, should play a role of triggering additional private investment such as FDI into poor countries, inducing local financing, contributing to make pro-business environment, and pro-poor development. It is worth noticing and further study that major donor agencies such as USAID, CIDA, and SIDA, GTZ have reported at $\mathrm{HLF}-4$ in Busan to assist financial guarantee programs as innovative approaches. ${ }^{29)}$

These days Global PPP has emerged with a fascinating trend of ODA especially in financially-strapped Africa. Despite this, Farlam (2005) has reported that, based on African case studies, the result of PPP in Africa over the last 15 years is mixed, and the process is complex, so governments should not expect PPP to be a 'magic bullet'. Global PPP should not put business profit or bureaucratic position first, but people in poverty first.

28) Clause 32 in the Statement of Busan Declaration

29) It is well-known as Patient Capital, Impact Investment, Early Investment and Social Entrepreneur and so on. 
Annex 1. Donor Definitions - PPP30)

\begin{tabular}{|c|c|}
\hline Nan & Definition of PPP \\
\hline Global Compact & $\begin{array}{l}\text { "... to identify common ground between the private and the public sectors and to } \\
\text { combine the skills and expertise of the private sector with the public sector's } \\
\text { legitimacy and knowledge of development issues." } \\
\text { PPPs are means towards reaching the ends defined by CSR - CSR is the goal or } \\
\text { the ideal, while PPPs are a strategy for attaining the goal }\end{array}$ \\
\hline $\begin{array}{c}\text { African Development } \\
\text { Bank }\end{array}$ & $\begin{array}{l}\text { "PPPs usually take the form of contracts between private sector entities and } \\
\text { government. They call for the private sponsor to deliver a desired service and } \\
\text { assume the associated risks. The government may already be providing that service, } \\
\text { or it may be a service that would benefit the country and economy but is not } \\
\text { currently being provided. The nature of the partnership can range from fairly simple } \\
\text { contractual arrangements for the supply a specific service, to complex agreements to } \\
\text { design, construct, operate, maintain, finance, and provide an infrastructure service." }\end{array}$ \\
\hline Asian Development Bank & $\begin{array}{l}\text { "Public private partnership (PPP) has been recognized in sustainable development } \\
\text { as a leading success factor towards sustainability and efficiency. A multi stakeholder } \\
\text { approach to good governance and development encompasses corporate and social } \\
\text { responsibility (CSR)." }\end{array}$ \\
\hline DFID & $\begin{array}{l}\text { Attracting private investment to spheres of activity traditionally regarded as the } \\
\text { responsibility of the public sector. ".... if the Millennium Development Goals are to } \\
\text { be achieved, the attraction of increased private sector investment in infrastructure } \\
\text { service provision in the poorer developing countries will be essential." }\end{array}$ \\
\hline UNDP & $\begin{array}{l}\text { Through PPPS, companies can ensure that their good intentions as defined by CSR } \\
\text { codes are translated into effective and appropriate results, also increasing knowledge } \\
\text { and resources, and establishing new ways of doing business. Attainment of MDGs } \\
\text { impossible without PPPS. }\end{array}$ \\
\hline IDB & $\begin{array}{l}\text { Strategic partnership for the provision of goods and services. Inherent risks in the private } \\
\text { sector necessitate the establishment of safeguards. Can be used to build policy dialogue } \\
\text { to promote important items in the development agenda within the private sphere. }\end{array}$ \\
\hline USAID & $\begin{array}{l}\text { "USAD is working to mobilize the ideas, efforts and resources of governments, } \\
\text { businesses and civil society by forging public-private alliances to stimulate economic } \\
\text { growth, develop businesses and workforces, address health and environmental issues, and } \\
\text { expand access to education and technology. Alliances incorporate a diverse array of } \\
\text { USAID and partner resources to arrive at solutions only available through pooled efforts." }\end{array}$ \\
\hline $\mathbb{I F C}$ & $\begin{array}{l}\text { "Public-private partnerships are contractual arrangements that allow governments to } \\
\text { benefit from private sector expertise, management, and finance, helping expand access } \\
\text { to public services such as water and sanitation, transport, power, and education." }\end{array}$ \\
\hline UNIDO & $\begin{array}{l}\text { "Partnerships can be an effective industrial development tool in such cases, especially } \\
\text { for SME development. They can be defined as structures for joint action in which } \\
\text { complementary resources (know-how, skills, funding, and equipment) can be tapped } \\
\text { and different interests balanced while the parties involved retain full independence." }\end{array}$ \\
\hline
\end{tabular}

30) Modified by author from annex 5 of Kirkemann \& Applelquist (2008) 


\title{
Annex 2. DAC Guideline on Promoting Private Investment for Development: THE ROLE OF ODA (2006, DAC Guidelines and Reference Series)
}

\author{
DAC Guideline on Promoting Private Investment for Development: THE ROLE OF ODA
}

I) Be more strategic, and their interventions need to be harmonized and guided by more systematic learning of lessons.

ii) Focus on helping to lower the costs of investment, reduce risks, improve competition and develop human and institutional capacities in developing countries.

iii) Give high priority to economic infrastructure investment and financial market development, as key areas for promoting investment in the near term.

iv) Pay greater attention to the determinants of domestic investment, both formal and informal, and to strengthening the capacities of local firms to respond to new investment opportunities and to expand business relationships with foreign investors.

v) Enhance the contribution of investment to pro-poor growth (i.e. increase the impact of growth on poverty reduction) by making labor, land and other markets work better for the poor, tackling constraints to women's entrepreneurship, reducing barriers to formalization, promoting environmental sustainability, expands access to knowledge and technology and unleashing the economic potential in rural areas.

vi) Encourage entrepreneurship and innovation by supporting education and vocational training, research and development activities and technology transfers.

vii) Promote responsible business practices in such areas as labor relations, the environment and anti-corruption.

viii) Build on analyses of country and sector-specific constraints, at national and local levels, to private sector development and encourage publication and public debate about the results. Help build up the capacities of developing countries to carry out such assessments.

ix) Seek out reliable, representative and accountable domestic partners who can drive reform programmers and help catalyze change.

x) Use market-based approaches to supporting firms. Targeted assistance should avoid distortions and firms receiving direct support should be selected based on their expected capacity to innovate, create jobs and provide services at local market conditions.

xi) Promote structured and inclusive public-private dialogue, at national and local levels, so as to bring micro and small entrepreneurs and informal firms and workers into consultation and decision-making processes. This will help to build demand for reform and for investments that will improve the investment climate.

xii) Evaluate the cumulative impact of their interventions on promoting investment and share examples of successful and unsuccessful practices. 


\section{Reference}

ADB. "Public-Private Partnership Handbook." Manila: ADB, 2006.

Addison Tony, Mavrotas George. "DEVELOPMENT ASSISTANCE AND DEVELOPMENT FINANCE: EVIDENCE AND GLOBAL POLICY AGENDAS." "Journal of International Development”, 2005: 819-836.

Buse \& Walt. “Global PPP: part I - a new development in health?”Bull of WHO, vol.78, no.4, 2000, retrieved from http://www. scielosp.org/scielo.php?script= sci_arttext\&pid=S0042-96862000000400019\&lng=en\&nrm=iso (2011.June.3).

Chattergee et all. "Where Has All the Money Gone? Foreign Aid and the Quest for Growth.” Bonn: The Institute for the Study of Labor (IZA), 2007.

Chris Sakellariou. "Benefits of general vs vocational/technical education in Singapore using quantile regression." "Internatinal Journal of Manpower" Vol.27, No: 4 (2006): 358-376.

CIDA. "Executive Report on the Evaluation of the CIDA Industrial Cooperation(CIDA-INC) Program.” 2007.

Clapp-Wincek Cynthia. “An Assessment of USAID's Global Development Alliances.” Bureau for Policy and Program Coordination, 2004.

DAC Reference documnet. "Promoting Private Investment for Development:The role of ODA. 2006.

DAC. “UPDATE ON PRIVATE SECTOR AND AID EFFECTIVENESS.” DAC, Working Party on Aid Effectiveness, 2010.

DCD. “SPECIAL REVIEW OF KOREA." 2008.

DCD/OECD. "GUIDING PRINCIPLES ON USING INFRASTRUCTURE TO REDUCE POVERTY.” 2006.

Djikic Samir. "G-20 Initiative Honours European Fund of Southeast Europe." Retrieved from http://news, freechal. com/IT/NEWSITview . asp? Lcat=03\&Mcat=003\&docid=243860 (2011.July.19).

Farlam Peter. "Assessing Public-Private Partnerships in Africa." SAIIA National Office Bearers, 2005. 
Jay-Hyung Kim et all. "Public-Private Partnership Infrastructure Projects: Case Studies from Republic of Korea.” Manila: ADB, KDI, 2011.

Kirkemann \& Applelquist. "Evaluation Study Public Private Partnership Programme." Ministry of Foreign Affairs, Danida, 2008.

Klein \& Harford. "The Market for Aid.” World Bank Publications, 2005.

Martinussen \& Pedersen. “AID-Understanding International Development Cooperation.” 2003.

Moyo Dambisa. "Dead Aid." New York: Farrar, Straus and Giroux, 2009.

Rodrik. "Getting interventions right: How South Korea and Taiwan grew rich." Massachusette: Cambridge, 1994, 53.

Sachs.J "The end of poverty." New York: Penguin Press, 2005.

Tilak Jandhyala B G. "Vocational Education and Training in Asia." , "The International Handbook of Educational Research in the Asia-Pacific Region”, editors Keeve Watanabe, 673-686. Springer, 2003

World Bank. "World Bank-Civil Society Engagement: Review of Fiscal Years 2007 to 2009." Washington D.C. 2009.

World Bank. "Migration and Remittance Factbook 2011." Washington D.C. Nov. 2010. Retrieved from http://data. worldbank. org/data-catalog/migration-and-remittances, 2011.Aug.12. 